\title{
Total hepatic ischemia and reperfusion after state controlled hemorrhagic shock, with used of different solutions: effects of neutrophils sequestration in kidney of rats $^{1}$
}

\author{
Isquemia e reperfusão hepática total após estado de choque hemorrágico controlado \\ com uso de diferentes soluções: efeitos no seqüestro de neutrófilos no rim de ratos
}

\author{
Elcio Shiyoiti Hirano², Mario Mantovani ${ }^{3}$, Rosana Celestina Morandin ${ }^{4}$, Jarbas de Brito ${ }^{5}$, Lilian Pavani ${ }^{6}$ \\ 1. Research developed in Laboratory of Investigation in Trauma Surgery, from Trauma Surgery Division of the Department of Surgery, \\ Faculty of Medical Sciences, University of Campinas (UNICAMP), São Paulo - Brazil. From Post-Graduation Program. \\ 2. MSc., Trauma Surgery, Supervisor and Physician of Unit of Emergency-Unicamp, Campinas, SP. Surgeon and Coordinator of Emergency \\ Department of the Municipal Hospital of Jaguariúna-SP (Asamas). \\ 3. Ph.D., Full Professor, Chief - Trauma Surgery Discipline, Department of Surgery, Faculty of Medical Sciences, Unicamp, Campinas, SP-Brazil. \\ 4. Ph.D., Biology, Unicamp, Campinas, SP-Brazil. \\ 5. MSc., Pathology, Federal University Fluminense, Full Professor of Faculty of Medicine, Itajubá, MG-Brazil. \\ 6. Biologist student, UNICAMP, Campinas, SP-Brazil.
}

\begin{abstract}
Purpose: To evaluate and compare neutrophils sequestration in the renal cortex of rats, result of total hepatic ischemia and reperfusion after controlled hemorrhagic shock, with use of different electrolytic solutions. Methods: Used 18 rats Wistar, males, adult, divided into three groups as the solution used to reanimation: Group PSS: physiologic saline solution; Group HSS: hypertonic saline hypertonic (7,5\%) followed by lactated ringer's solution; Group LRS: lactated ringer's solution. All the animals were submitted to the bleeding controlled until mean arterial pressure (MAP) $40 \mathrm{mmHg}$, for $20 \mathrm{minutes}$. Performed volemic replacement until PAM=80 $\mathrm{mmHg}$ with the solution according the studied group, followed by laparotomy and Pringle's Maneuver for 15 minutes. The animals were accompanied until for two hours. To statistical comparisons between mean of neutrophils sequestration, in interstitium of the renal cortex, were made the tests One-way ANOVA and covariance analysis, adjusting itself for time of supervened. The hemodynamic parameters evaluated were: MAP, heat rate, cardiac index, vascular resistance system index. The analyzed metabolic variables were: $\mathrm{pH}$, bicarbonate, base deficit and lactato, besides electrolytes. Results: The mean values of supervened, in minutes, for group were: Group PSS 79,0 $\pm 12,0$;

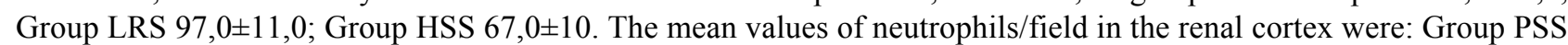
$0,55 \pm 0,68$; Group LRS 1,68 $\pm 0,53$; Group HSS 1,33 $\pm 0,43$. When adjusted for time of supervened: Group PSS 0,55; Group LRS 1,62; Group HSS 1,39. There was statistically significant difference in neutrophils sequestration, between Group PSS regarding the others groups, using itself or not the adjustment by time of supervened ( $p=0,016$ and $p=0,0128)$. Conclusion: Both critical situations in this model, controlled hemorrhagic shock followed by Pringle's maneuver, promoted neutrophils sequestration in the interstitium renal of rat, and the physiologic saline solution demonstrated minor mean, differentiating statistically of the others solutions
\end{abstract}

Key words: Neutrophils. Kidney. Ischemia. Reperfusion. Liver. Hypovolemia.

\section{RESUMO}

Objetivo: Avaliar e comparar o seqüestro de neutrófilos no rim de rato, como efeito da isquemia e reperfusão hepática total após estado de choque hemorrágico controlado, com uso de diferentes soluções eletrolíticas. Métodos: Utilizou-se 18 ratos Wistar, machos, adultos, divididos em três grupos conforme a solução utilizada para reanimação: Grupo SF: solução fisiológica; Grupo SH: solução hipertônica de $\mathrm{NaCl}$ a 7,5\% seguido pela solução de ringer com lactato; Grupo RL: solução de ringer com lactato. Todos os animais foram submetidos à sangria controlada até pressão arterial média (PAM) atingir 40 $\mathrm{mmHg}$, permanecendo por 20 minutos. Realizou-se reanimação volêmica até PAM=80 mmHg com a solução conforme o grupo estudado. Em seguida realizou-se uma laparotomia e a manobra de Pringle por 15 minutos. Os animais foram acompanhados até duas horas. Para comparações estatísticas entre as contagens de neutrófilos, no interstício do córtex renal, foram efetuados os testes ANOVA e a análise de covariância, ajustando-se para o tempo de sobrevida. Os parâmetros hemodinâmicos avaliados foram: PAM, freqüência cardíaca, índice cardíaco, índice de resistência vascular sistêmica. As variáveis metabólicas analisadas foram: $\mathrm{pH}$, bicarbonato, reserva de base e lactato, além de eletrólitos. Resultados: Os

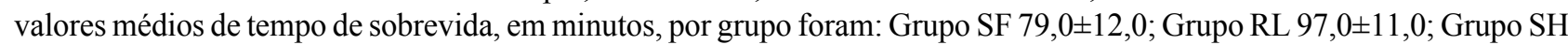
$67,0 \pm 10$. Os valores médios da contagem de neutrófilos/campo no córtex renal foram: Grupo SF 0,55 $\pm 0,68$; Grupo RL

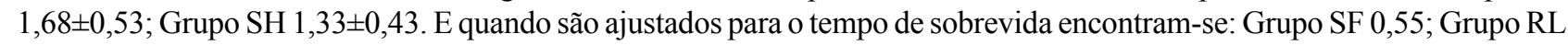


1,62; Grupo SH 1,39. Houve diferença estatisticamente significativa, na contagem de neutrófilo entre o Grupo SF com os demais, usando-se ou não o ajuste pelo tempo de sobrevida $(\mathrm{p}=0,016$ e $\mathrm{p}=0,0128)$. Conclusão: As duas situações críticas, choque hemorrágico controlado e manobra de Pringle, promoveram seqüestro de neutrófilos no interstício renal do rato, sendo a solução fisiológica com a menor média, diferenciando estatisticamente das demais soluções, neste modelo.

Descritores: Neutrófilos. Rim. Isquemia. Reperfusão. Fígado. Hipovolemia.

\section{Introduction}

In Brazil, the trauma is the principal causes of mortality in young adult and hemorrhagic shock (HS) is one of the critical situations present in the majority of major traumatism. Depending on duration and intensity, the HS becomes responsible for the beginning of the Syndrome Inflammatory Response Systemic (SIRS), activating neutrophils, which adhere to endothelium and for diapedesis sequestration on interstitium of the organs, where they initiate the production of free radical $\left(\mathrm{O}_{2}^{-}\right)$, and promoting lesion local. During stress, as trauma, the bone marrow increases production of neutrophils $\left(1 \times 10^{6} / \text { second }\right)^{1}$. Eurenius and Brouse ${ }^{2}$ demonstrated neutrophilia in 4 hours in experimental model in mouse with thermal lesion, after this period occur neutropenia. As the literature, the sequestration of neutrophils in the liver and lung it initiates within two hours of reperfusion 3,4 . In the major hepatic trauma, Pringle's maneuver (PM) is used to the control of bleeding, while performing the surgical procedure. However, this maneuver promotes an ischemia hepatic, what it accentuates for hypoxia previously promoted by HS. The lesion by hypoxia in this situation is exacerbated when occurs hepatic reperfusion at the moment in which it undone the PM. The initial treatment to HS is replacement fluids, situation which promotes reperfusion of the ischemic area. This condition is equal as second stimulus for increase of the production on free radicals by neutrophils, for demand of the oxygen. There are other alterations as: anaerobic metabolism, metabolic acidosis (consumption of the base reserve, increase of the lactate), production of inflammatory mediators and cellular lesion. Therefore, the reperfusion increases the lesion tissular promoted by local ischemia and associated or no with HS, characterizing Reperfusion Syndrome ${ }^{5}$. The neutrophils activated sequestration of indiscriminate form in the interstitium of the normal or injured organs, initiating the installation of SIRS, which as intensity and duration can be followed by Multiple Organ and System Failure $^{6}$. Currently, in the literature it study which adequate reanimation form and ideal solution that would promote less manifestation of the SIRS ${ }^{7}$. Therefore, this study has as goal evaluate the sequestration of neutrophils in the renal cortex of rats, submitted front two criticals conditions, the HS and PM, using different solutions for volemic replacement.

\section{Methods}

In this research were used 18 males Wistar rats, weights ranging from 180 to $240 \mathrm{~g}$, supplied by Unicamp, Campinas, SP-Brazil. The prodecures was approved in the Ethic Commission on Animal Experiment of the Biologic Institute of the Unicamp, Campinas, SP-Brazil (protocol n 363-1).
According to the literature ${ }^{8}$, opted by the intraperitoneal anesthesia with solution of cetamine cloridrate $(80 \mathrm{mg} / \mathrm{Kg})$ plus xilazine cloridrate $(10 \mathrm{mg} / \mathrm{Kg})$ with atropine $(0,05 \mathrm{mg} /$ $\mathrm{Kg}$ ). After anesthesia the animal was placed in a supine position on a board with heat controlled electrically, with rectal temperature between $37-38,5^{\circ} \mathrm{C}$. The right carotid artery and right jugular vein were dissected. A polyethylene catheter (PE 50), previously heparinezed, was place on vein, and a probe of central temperature, followed by administration of oxygen ( 2 litres/minutes). The left femoral artery was dissected and polyethylene catheter $24 \mathrm{G} 3 / 4(0,7$ $\mathrm{x} 19 \mathrm{~mm}$ ), previously heparinezed. The control of the mean arterial pressure (MAP), blood samples and installation the controlled hemorrhagic shock (CHS) were performed by right femoral artery. The volume estimate to rat is $5,4 \mathrm{ml} / 100 \mathrm{~g}$ of weight. To initial CHS bleeding of volume of corresponding to $5 \%$ blood volume estimate until MAP of $60 \mathrm{mmHg}$, instant the bleeding changed for $2,5 \%$ blood volume estimate, until obtain MAP of $40 \mathrm{mmHg}^{9}$. The right jugular vein were performed volemic replacement, measured central venous pressure (CVP) and determination of the cardiac outpout (CO) for thermodilution. In each phase of the experiment were evaluated the next variables: MAP, heart rate (HR), electrocardiogram (ECG), CVP and CO. Concomitantly, with blood samples collected of the right femoral artery were evaluated: blood gases, sodium $\left(\mathrm{Na}^{+}\right)$, potassium $\left(\mathrm{K}^{+}\right)$, hemoglobin $(\mathrm{Hb})$, hematocrit $(\mathrm{Ht})$. The arterial lactate $(\mathrm{Lac})$ was measured by Test BM- Lactate ${ }^{\circledR}$ (Roche). All the animals were submitted for $\mathrm{CHS}$ with $\mathrm{MAP}=40 \mathrm{mmHg}$ for 20 minutes (20'), then a volemic replacement until $\mathrm{MAP}=80 \mathrm{mmHg}$ with solution according the studied group, keeping for 10 minutes, followed immediately of laparotomy and PM for 15 minutes (15') and followed by period of reperfusion until 120 minutes (120PR), keeping MAP > $40 \mathrm{mmHg}$. Each volume replaced of solution crystalloid, except solution hypertonic, was $5 \%$ of volemia estimate of each animal. Performed three volume replaced of fluid followed by one blood. The animals were randomized in three groups:

1) Group lactated Ringer's solution $\left(39-40^{\circ} \mathrm{C}\right)(\mathrm{LRS})$ and blood to volemic replacement after CHS and maintenance MAP $>40 \mathrm{mmHg}$ during Pringle's maneuver and 120PR.

2) Group physiologic saline solution $\left(39-40^{\circ} \mathrm{C}\right)$ (PSS) and blood to volemic replacement after CHS. To maintenance MAP $>40 \mathrm{mmHg}$ during Pringle's maneuver and 120PR was used LRS and blood.

3) Group hypertonic saline solution 7,5\% $\left(39-40^{\circ} \mathrm{C}\right)$ (HSS), used $4 \mathrm{ml} / \mathrm{kg}$, only one infusion and complemented with LRS and blood for volemic replacement after CHS and maintenance MAP $>40 \mathrm{mmHg}$ during Pringle's maneuver and 120PR. 
The Figures $1 \mathrm{~A}$ and $1 \mathrm{~B}$ showed identification the hepatoduodenal ligament and performed clamped (Pringle's maneuver) for 15 '.

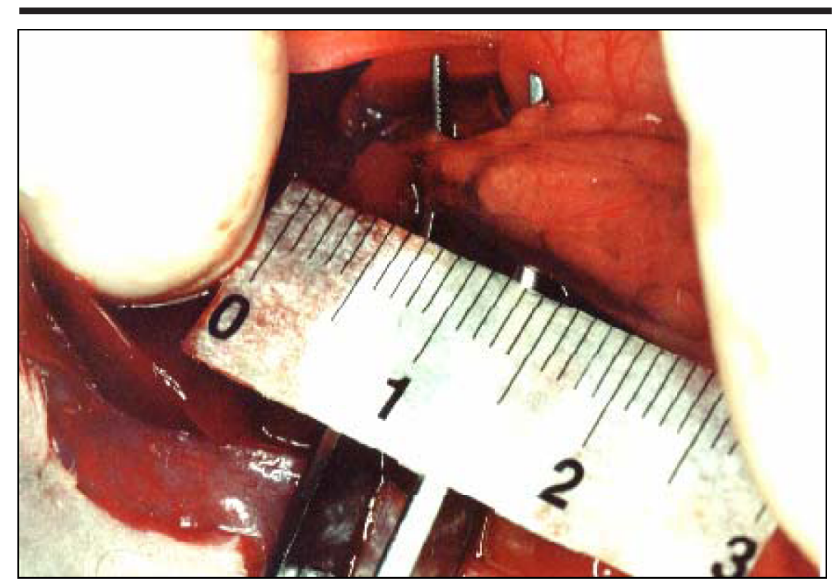

FIGURE 1A - Demonstrates the hepatoduodenal ligament.

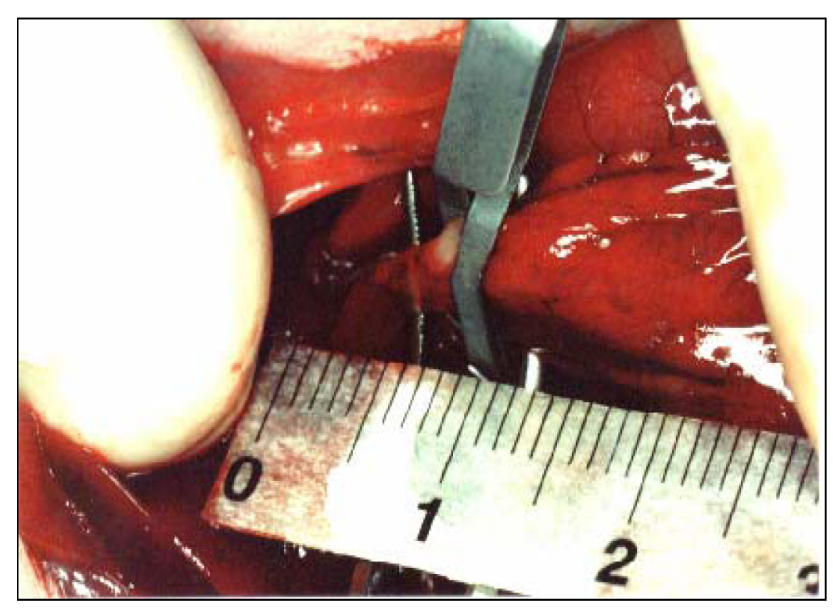

FIGURE 1B - Demonstrates the Pringle's maneuver.

After PM the animals were accompanied until 120', and the survivors were sacrificed with bleeding by right femoral artery. The morphologic analysis was made after reperfusion with buffered formalin with sals of sodium phosphate and $\mathrm{pH}$ neutral for 10 minutes through the right femoral artery, with the aorta clamped below diaphragm and exists of liquid through opening in the inferior cava vein. The hematoxylin-eosin staining was method utilized. The counting of interstitial neutrophils in the renal cortex was realized per field. The results was arithmetic mean in 10 microscope optic (MO) fields (magnified 400x) . The MO was performed analyzing one field passed two equal field so that it examined the next (Figure 2). To compare the measures obtained in an only moment between the 3 groups was used the One-way ANOVA method (Variance Analysis) and Tukey's Test for multiple comparison. Due to the dispersion and asymmetry of the values of some variable, it was used the logarithmic transformation. To compare the measures between the 3 groups and between the 3 times was used the Variance Analysis for repeated measures (Repeated Measures ANOVA). To compare the measures among groups was used Tukey's Test for multiple comparison, and to compare the measures between times was used the profile test for contrasts. In the correlation among variables was used the correlation coefficient of Pearson. The curves of supervened were estimate by Kaplan-Meier's Method and used Breslow's Tests and LogRank. The relation between supervened and other variable was studied through the Regression Analysis of Cox, with model of proportional risks. For neutrophis counting was used the Analysis of Lineal Regression. The significant level of $5 \%(p<0,05)$ was utilized.

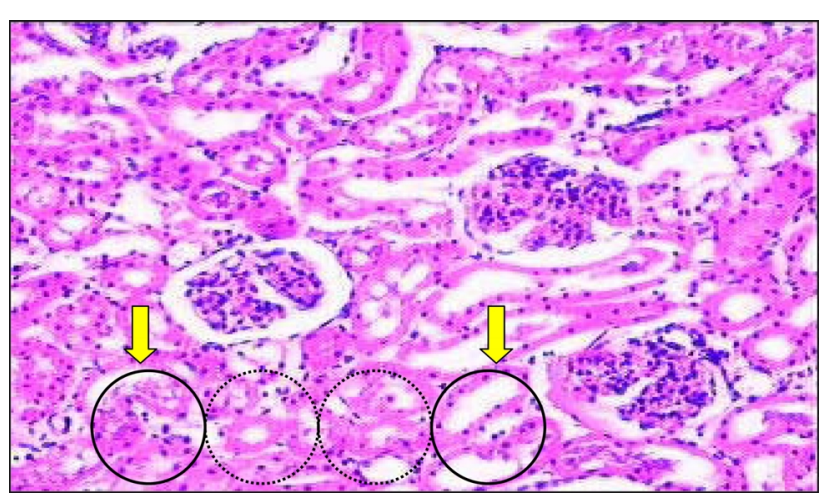

FIGURE 2 - The arrows indicate the examined field, according the demonstrated sequence.

\section{Results}

The initial means values, end of CHS and of PM of the hemodynamic variables are demonstrated in the Table 1 . The MAP, HR, cardiac index (CI) and vascular resistance systemic index (VRSI) did not demonstrated statistical difference among groups. The Table 2 demonstrates the means values of $\mathrm{pH}$, bicarbonate, base deficit (BD) and Lac, in the next phases: beginning and the end of CHS and of PM. In the reperfusion period of 60 minutes (RP60) was measured Lac. At the beginning and end of the experiment of CHS the metabolic variables did not showed statistical differences among groups. However, there was statistical difference at the end of PM in the next variables: $\mathrm{pH}$, and DB. The mean value of Lac of the Group HS differed statistically of the other in the phase PR60. The Table 3 demonstrates the mean values of the electrolytes in the phases: beginning, end of the CHS, PM and of PR60. Only the mean value of the sodium it demonstrated statistically different among groups at the end of PM $(p=0,002)$. The determination of hematocrit in the beginning, at the end of CHS, PM and PR60 are demonstrated in the Table 4. The statistical analysis of the mean values of hematocrit demonstrated there was difference among groups in PR60. The Table 5 demonstrates the supervened of the animals during the experiment. The Table 6 demonstrated neutrophils of counting for field in each group. The Group PSS differed statistically of the other groups, with minor mean value, even with adjustment with the supervened ( $\mathrm{p}=0,0166$ and 0,0128 , respectively). 
TABLE 1 - Initial means values of the hemodynamic variables.

\begin{tabular}{|c|c|c|c|c|c|c|c|c|c|c|}
\hline \multirow[b]{2}{*}{ Group } & \multirow{2}{*}{$\begin{array}{c}\begin{array}{c}\text { MAP } \\
(\mathrm{mmHg})\end{array} \\
\text { Initial }\end{array}$} & \multicolumn{3}{|c|}{$\begin{array}{l}\text { HR } \\
(\min )\end{array}$} & \multicolumn{3}{|c|}{$\begin{array}{c}\mathrm{IC} \\
(\mathrm{mL} / \mathrm{min} / \mathrm{dm} 2)\end{array}$} & \multicolumn{3}{|c|}{$\begin{array}{c}\text { RVSI } \\
(\mathrm{mmHg} / \mathrm{mL} / \mathrm{min} / \mathrm{dm} 2)\end{array}$} \\
\hline & & Iniiial & CHS & MP & Inicio & CHC' & MP & Inicio & $\mathrm{CHC}$ & MP \\
\hline PSS & $\begin{array}{l}128,5 \\
\pm 22,92\end{array}$ & $\begin{array}{l}289,7 \\
\pm 31,63\end{array}$ & $\begin{array}{l}296,7 \\
\pm 60,88\end{array}$ & $\begin{array}{l}270,0 \\
\pm 31,62\end{array}$ & $\begin{array}{l}27,8 \\
\pm 4,4\end{array}$ & $\begin{array}{l}12,4 \\
\pm 3,8\end{array}$ & $\begin{array}{l}16,0 \\
\pm 4,1\end{array}$ & $\begin{array}{l}4,65 \\
\pm 0,75\end{array}$ & $\begin{array}{l}3,59 \\
\pm 1,43\end{array}$ & $\begin{array}{l}2,39 \\
\pm 0,59\end{array}$ \\
\hline LRS & $\begin{array}{l}137,8 \\
\pm 12,42\end{array}$ & $\begin{array}{l}281,0 \\
\pm 44,50\end{array}$ & $\begin{array}{l}262,0 \\
\pm 64,93\end{array}$ & $\begin{array}{l}299,0 \\
\pm 49,55\end{array}$ & $\begin{array}{l}25,0 \\
\pm 6,2\end{array}$ & $\begin{array}{l}9,6 \\
\pm 2,3\end{array}$ & $\begin{array}{l}16,6 \\
\pm 4,1\end{array}$ & $\begin{array}{l}5,79 \\
\pm 1,43\end{array}$ & $\begin{array}{l}4,14 \\
\pm 0,91\end{array}$ & $\begin{array}{l}2,82 \\
\pm 1,05\end{array}$ \\
\hline HSS & $\begin{array}{l}117,3 \\
\pm 19,24\end{array}$ & $\begin{array}{l}335,0 \\
\pm 44,61\end{array}$ & $\begin{array}{l}305,0 \\
\pm 32,71\end{array}$ & $\begin{array}{l}275,0 \\
\pm 25,88\end{array}$ & $\begin{array}{l}26,4 \\
\pm 14,0\end{array}$ & $\begin{array}{l}11,4 \\
\pm 6,6\end{array}$ & $\begin{array}{l}22,9 \\
\pm 10,8\end{array}$ & $\begin{array}{l}6,00 \\
\pm 3,79\end{array}$ & $\begin{array}{l}3,69 \\
\pm 1,52\end{array}$ & $\begin{array}{l}1,97 \\
\pm 1,19\end{array}$ \\
\hline $\mathrm{p}^{*}$ & 0,198 & 0,078 & 0,377 & 0,375 & 0,871 & 0,576 & 0,207 & 0,583 & 0,747 & 0,345 \\
\hline
\end{tabular}

* Anova.

TABLE 2 - Means values of metabolic parameters.

\begin{tabular}{|c|c|c|c|c|c|c|c|c|c|c|c|c|c|}
\hline \multirow[b]{2}{*}{ Group } & \multicolumn{3}{|c|}{$\mathbf{p H}$} & \multicolumn{3}{|c|}{$\begin{array}{c}\text { Bicarbonate } \\
(\mathrm{mmol} / \mathrm{L})\end{array}$} & \multicolumn{3}{|c|}{$\begin{array}{c}\text { Base deficit } \\
(\mathrm{mmol} / \mathrm{L})\end{array}$} & \multicolumn{4}{|c|}{$\begin{array}{c}\text { Lactate } \\
(\mathrm{mmol} / \mathrm{L})\end{array}$} \\
\hline & Initial & CHS & PM & Initial & CHS & PM & Initial & CHS & PM & Initial & CHs & PM & RP 60 \\
\hline$\overline{\text { PSS }}$ & $\begin{array}{l}7,30 \\
\pm 0,05\end{array}$ & $\begin{array}{l}7,28 \\
\pm 0,05\end{array}$ & $\begin{array}{l}7,21 \\
\pm 0,03\end{array}$ & $\begin{array}{l}25,52 \\
\pm 0,91\end{array}$ & $\begin{array}{l}15,93 \\
\pm 3,82\end{array}$ & $\begin{array}{l}15,02 \\
\pm 2,73\end{array}$ & $\begin{array}{l}-1,08 \\
\pm 1,42\end{array}$ & $\begin{array}{l}-8,93 \\
\pm 3,63\end{array}$ & $\begin{array}{l}-11,3 \\
\pm 2,13\end{array}$ & $\begin{array}{l}1,10 \\
\pm 0,25\end{array}$ & $\begin{array}{l}5,52 \\
\pm 1,61\end{array}$ & $\begin{array}{l}4,18 \\
\pm 1,15\end{array}$ & $\begin{array}{l}3,16 \\
\pm 0,85\end{array}$ \\
\hline$\overline{\text { LRS }}$ & $\begin{array}{l}7,30 \\
\pm 0,04\end{array}$ & $\begin{array}{l}7,32 \\
\pm 0,04\end{array}$ & $\begin{array}{l}7,30 \\
\pm 0,04\end{array}$ & $\begin{array}{l}26,73 \\
\pm 1,38\end{array}$ & $\begin{array}{l}15,47 \\
\pm 2,15\end{array}$ & $\begin{array}{l}17,37 \\
\pm 1,66\end{array}$ & $\begin{array}{l}0,02 \\
\pm 1,90\end{array}$ & $\begin{array}{l}-8,62 \\
\pm 1,18\end{array}$ & $\begin{array}{l}-7,80 \\
\pm 1,05\end{array}$ & $\begin{array}{l}1,22 \\
\pm 0,44\end{array}$ & $\begin{array}{l}6,05 \\
\pm 1,45\end{array}$ & $\begin{array}{l}6,22 \\
\pm 1,06\end{array}$ & $\begin{array}{l}3,93 \\
\pm 1,39\end{array}$ \\
\hline$\overline{\text { HSS }}$ & $\begin{array}{l}7,31 \\
\pm 0,06\end{array}$ & $\begin{array}{l}7,27 \\
\pm 0,06\end{array}$ & $\begin{array}{l}7,25 \\
\pm 0,06\end{array}$ & $\begin{array}{l}26,12 \\
\pm 1,83\end{array}$ & $\begin{array}{l}15,95 \\
\pm 2,20\end{array}$ & $\begin{array}{l}15,68 \\
\pm 1,79\end{array}$ & $\begin{array}{l}-0,05 \\
\pm 1,71\end{array}$ & $\begin{array}{l}-7,42 \\
\pm 3,54\end{array}$ & $\begin{array}{l}-9,85 \\
\pm 1,55\end{array}$ & $\begin{array}{l}1,48 \\
\pm 0,60\end{array}$ & $\begin{array}{l}4,40 \\
\pm 1,49\end{array}$ & $\begin{array}{l}5,95 \\
\pm 2,59\end{array}$ & $\begin{array}{l}6,37 \\
\pm 2,53\end{array}$ \\
\hline P* & 0,925 & 0,228 & 0,012 & 0,364 & 0,947 & 0,174 & 0,468 & 0,663 & 0,007 & 0,358 & 0,192 & 0,123 & 0,015 \\
\hline
\end{tabular}

*Anova.

TABLE 3 - Mean values of sodium and potassium until PR60.

\begin{tabular}{|c|c|c|c|c|c|c|c|c|}
\hline \multirow[b]{2}{*}{ Group } & \multicolumn{4}{|c|}{$\begin{array}{l}\text { Sodium } \\
(\mathrm{mEq} / \mathrm{L})\end{array}$} & \multicolumn{4}{|c|}{$\begin{array}{l}\text { Potassium } \\
(\mathrm{mEq} / \mathrm{L})\end{array}$} \\
\hline & Initial & CHS & MP & RP60 & Initial & CHS & MP & RP60 \\
\hline PSS & $\begin{array}{l}137,2 \\
\pm 2,32 \\
\end{array}$ & $\begin{array}{l}130,5 \\
\pm 2,74 \\
\end{array}$ & $\begin{array}{l}137,2 \\
\pm 1,47 \\
\end{array}$ & $\begin{array}{l}142,2 \\
\pm 5,17 \\
\end{array}$ & $\begin{array}{l}5,68 \\
\pm 0,54 \\
\end{array}$ & $\begin{array}{l}7,98 \\
\pm 0,90 \\
\end{array}$ & $\begin{array}{l}7,15 \\
\pm 0,66 \\
\end{array}$ & $\begin{array}{l}7,68 \\
\pm 1,74\end{array}$ \\
\hline LRS & $\begin{array}{l}135,3 \\
\pm 4,23\end{array}$ & $\begin{array}{l}128,3 \\
\pm 3,72\end{array}$ & $\begin{array}{l}132,8 \\
\pm 3,54\end{array}$ & $\begin{array}{l}135,8 \\
\pm 10,55\end{array}$ & $\begin{array}{l}5,12 \\
\pm 0,52\end{array}$ & $\begin{array}{l}7,62 \\
\pm 1,73\end{array}$ & $\begin{array}{l}6,90 \\
\pm 0,89\end{array}$ & $\begin{array}{l}8,08 \\
\pm 1,64\end{array}$ \\
\hline HSS & $\begin{array}{l}134,7 \\
\pm 1,86\end{array}$ & $\begin{array}{l}132,0 \\
\pm 7,72\end{array}$ & $\begin{array}{l}140,5 \\
\pm 3,39\end{array}$ & $\begin{array}{l}141,5 \\
\pm 4,76\end{array}$ & $\begin{array}{l}5,57 \\
\pm 1,05\end{array}$ & $\begin{array}{l}8,02 \\
\pm 1,46\end{array}$ & $\begin{array}{l}7,72 \\
\pm 1,64\end{array}$ & $\begin{array}{l}6,37 \\
\pm 2,53\end{array}$ \\
\hline p* & 0,344 & 0,48 & 0,002 & 0,282 & 0,408 & 0,864 & 0,463 & 0,332 \\
\hline
\end{tabular}

*Anova.

TABLE 4 - Determination of hematocrit.

\begin{tabular}{lllll}
\hline \multicolumn{5}{c}{ Hematocrit(\%) } \\
\hline Group & Inítial & CHS & PM & RP60 \\
\hline PSS & 42,83 & 29,83 & 25,50 & 39,33 \\
& $\pm 2,48$ & $\pm 2,48$ & $\pm 3,27$ & $\pm 2,52$ \\
\hline \multirow{2}{*}{ RS } & 43,50 & 31,33 & 24,83 & 41,80 \\
& $\pm 2,17$ & $\pm 1,03$ & $\pm 3,97$ & $\pm 3,03$ \\
\hline HSS & 42,67 & 31,17 & 24,50 & 30,50 \\
& $\pm 3,08$ & $\pm 4,26$ & $\pm 6,60$ & $\pm 5,17$ \\
\hline $\mathbf{p}^{*}$ & 0,844 & 0,627 & 0,936 & 0,000 \\
\hline
\end{tabular}

*Anova
TABLE 5 - Time of supervened in minutes for group (according Kaplan-Meier).

\begin{tabular}{lcccc}
\hline Group & Méan & $\begin{array}{c}\text { Standard } \\
\text { deviation }\end{array}$ & $\begin{array}{c}\text { reliable interval } \\
\mathbf{9 5 \%}\end{array}$ & Median \\
\hline PSS & 79,0 & 12,0 & $(55,0-103,0)$ & 67,0 \\
LRS & 97,0 & 11,0 & $(76,0-117,0)$ & 95,0 \\
HSS & 67,0 & 10,0 & $(46,0-87,0)$ & 57,0 \\
\hline
\end{tabular}


TABLE 6 - Neutrophils of counting/field in the renal cortex of rat.

\begin{tabular}{lccc}
\hline Group & mean/field & $\begin{array}{c}\text { Standard } \\
\text { deviation }\end{array}$ & $\begin{array}{c}\text { Mean adjusted } \\
\text { for time of } \\
\text { supervened }\end{array}$ \\
\hline PSS & 0,55 & 0,68 & 0,55 \\
LRS & 1,68 & 0,53 & 1,62 \\
HSS & 1,33 & 0,43 & 1,39 \\
\hline P* & 0,0166 & - & 0,0128 \\
\hline *Anova. & & &
\end{tabular}

\section{Discussion}

In the trauma, the shock main cause is the bleeding, which it can be located in the torso and extremities. The hemodynamic and metabolic parameters are used to evaluate a volemia circulating and effectiveness of reanimation. The vital signals aid in the diagnosis of the shock, however they can be normal due to the compensation mechanisms and of other factors. The installation of CHS based on model of the literature ${ }^{9}$. The HR did not showed alterations between experimental times in any of the groups in this study, probably in function of the drugs used in the anesthesia with effect in the cardiovascular system 8,10 . The CI introduced a significant reduction in the values end CHS in the three groups. After PM, the reduction regarding the basal values was preserved, except in the group HSS. Although it was not statistically different from other groups, the value elevated again, approaching the basal level of the group $(p<0,05)$, suggesting a recovery attempt. The results of VRSI showed a significant reduction after 15' of PM in the three groups, what it suggests disturbances in the control vasopressor in rat submitted to the shock and following of the hepatic ischemic, indicating phase uncontrolled of shock in installation ${ }^{11}$. Regarding the mean values of the metabolic parameters, the interference of the anesthesia can be identified in the decrease of $\mathrm{pH}$ arterial in the beginning of the study. The acidosis is caused by respiratory depression it can be seen by the mean values of bicarbonate, DB and Lac (table 2). The mean values of $\mathrm{O}_{2} \mathrm{kept}$ above $150 \mathrm{mmHg}$, by the supplement of oxygen $(100 \%)$ during experimental times. This depression of the respiratory system is described in rat anesthetized with the solution cetamine + xilazine in the necessary doses for the level surgical anesthetic 8,10 . Besides of volemic replacement in the Group PSS, where was increases significantly of metabolic acidosis after 15 minutes of ischemia hepatic in the Group PSS, when we compare the beginning value $(p=0,004)$. The dosage of Lac in PR60 (table 2), shows maintenance of high values in the group HSS, statistically different than occurs in the group PSS $(p=0,0234)$. Intermediary situation appears on the Group LRS, without significant difference with the other groups. Interesting is to observe that, although the IC pointed to improves hemodynamic in the animals that received hypertonic saline solution after CHS, the Lac showed tissue hypoperfusion persistent. The potassium in the presence of metabolic acidosis dislocates of the compartment intracellular for extracellular as compensation mechanism, promoted the increase serum level. At study present, was a verified elevation of the serum potassium during all the phases. The tissue injury due to poor perfusion and phase of reperfusion promotes the liberation of potassium.
The evolution of the level serum potassium showed comportment equal with metabolic acidosis. To RP 60, the electrolyte maintained itself in high levels to the basal, independent of solution utilized. The Groups HSS and PSS showed statistically difference the levels serum sodium with Group LRS after PM ( $\mathrm{p}=0,0016)$, however the difference disappears in RP60, probably because were sodium chloride solutions. In the Group HSS showed major elevation after the initial volemic replacement, after CHS, when a hypertonic saline solution was used. By installation of CHS occurs mobilization of the intracellular fluid and interstitial, as compensation mechanism, for the intravascular compartment, promoting the decreased of hematocrit, how was observed in the study 12,13 . PM accentuates hypovolemia state due to the stagnation in the splanchnic circulation and consequent decrease of the volemia, demanding administration of high volume replacement for maintenance MAP $>$ or $=40 \mathrm{mmHg}$, occurring hemodilution. In RP60, the values hemocytometry return to the basal levels, except in the Group HSS ( $p=0,0021$ ). After the shock, for elevation MAP to $80 \mathrm{mmHg}$, the volume replacement was minor in the Group HSS regarding the Group LRS ( $p=0,0361$ ), however both without significant differences with the Group ISS. In the next times, when used elevated volume replacement of lactate ringer's solution in all groups to maintenance of the pressure, the difference disappears. The Figure 3 demonstrates the curves of estimate supervened by Kaplan-Meier's Method. The table 5 exhibition that the supervened was not different in the three groups $(p=0,2002$, test of Breslow and $p=0,2435$, logrank test). Studying variable that could be influencing time of supervened, was verified that Lac measured in RP60 showed a value of $\mathrm{p}=0,0068$ and a risk relation of 1,41 to each unit, regardless of the group to which belongs the animal, showing again the importance of serum lactate as an indicator of the prognostic of the shock ${ }^{14}$. The neutrophis counting in the renal cortex showed in the table 6 exhibited statistical differences significant among crystalloids utilized, using itself or not the adjustment by time of supervened $(\mathrm{p}=0.0166$ and $\mathrm{p}=0.0128$, respectively), being the mean value minor was met in the Group ISS. The results of the analysis univaried of Lineal Regression to study the influence of the interest variables in neutrophis counting did not introduce association. Regarding the obtained results, initially should evaluate the used model. The occlusion of the portal triad in experimental models in rat, promoted elevated mortality when it remains above 30 minutes, in function of the circulatory collapse caused by congestion splanchnic, with mortality rate above $80 \% 15$. The Table 7 demonstrates the percentage of different organs regarding the weight in human and in rat 16,17

TABLE 7 - Comparison between rat and human, weight of the organ regarding of the body.

\begin{tabular}{lcccccc}
\hline & Intestine & Liver & Kidney & Lung & Heart & Brain \\
\hline Human & 4,2 & 2,1 & 0,4 & 1,2 & 0,5 & 2,3 \\
Rat & 7,46 & 3,3 & 0,75 & 1,13 & 0,59 & 0,99 \\
\hline
\end{tabular}

These differences can explain the seriousness of ischemia hepatic in the rat. Moreover, various studies showed that, despite reanimation for normal levels of pressure, for the hypoperfusion remain in the liver, small intestine, spleen and skeletal muscle 18,19 . The response to the reduction of the 
flow microcirculation occur hypoxia local and expense of the intracellular reserve of energy. It occurs, so, suppression of the immune function and lesion in organs and critical systems, as the kidney, liver and lung $20-21$. The renal injuries are caused by activated neutrophils that are accumulated in interstice where liberate proteases and elastases, generating free radical that contribute for toxic effect ${ }^{22}$. These events are initiated by the molecules proinflamatory production. Cytokines derivatives of the intestine during shock seem have important participation in the lesions of other organs, even without bacteria $^{23}$. The fluid used in reanimation can influence the answer proinflamatory after the shock 24,25 . The solutions crystalloids equilibrate freely among spaces intravascular and interstitial, expanding both compartments. The effect hemodynamic, however, has short duration, demanding frequently infusion of great volumes. The preference by the lactated ringer's solution regarding isotonic saline solution has as base the potential caused acidosis with high level of chlorine that can occur because is necessary elevated volume replacement in reanimation. However, several aspects have been discussed regarding lactated ringer's solution, a mixture racemic contend isomer $\mathrm{L}(+)$ and $\mathrm{D}(-), 14 \mathrm{milimol} / \mathrm{l}$ of each form. Besides producing several cardiac disturbances ${ }^{26}$, isomer $\mathrm{D}(-$ ) causes an oxygen reactive species increase, by neutrophils and affects the leukocytes genes expression involved in the phenomenon of the inflammation, the cellular migration and for apoptosis 27 . The induction of apoptosis in the small intestine and in the liver with lactate ringer's solution in reanimation after hemorrhagic shock was observed by Deb et $a l^{28}$, not occurring with the hypertonic saline solution or blood. The hypertonic saline solution $(7,5 \%)$ represents an option for the reduction of the infused volume, in function of the osmotic pressure and liquid redistribution for the compartment extracellular 29 . The hypernatremia and hyperosmolality are controlled by use of $4 \mathrm{~mL} / \mathrm{Kg}$, increasing of sodium from 10 to $15 \mathrm{~m} / \mathrm{EqL}^{30}$. Studies show the advantages of the use of the hypertonic solution ${ }^{31,32}$, like the reduction in the interaction between cells polymorphonucleares and endothelial, promoting reduction of neutrophils sequestration 24,33 . However, in specific conditions, as in the model that used dehydrated rats ${ }^{34}$, the mortality was smaller in the animals revived with lactated ringer's solution compared with hypertonic saline solution. McKirman et al ${ }^{35}$, model in pigs, obtained similar results. In a clinical study of meta-analysis 36 concluded that hypertonic saline solution with dextran was beneficial in patients with head injury. In function of the obtained results in this study and of the literature data, it would be expected that in the group HSS have less neutrophils sequestration in kidney and supervened larger. In fact, some results showed advantages in the use of the hypertonic saline solution, as volume replacement and improvement of the CI after 15 minutes of ischemia hepatic. Therefore, observed in status hemodynamic a recovery attempt in the Group HSS. However, is necessary to evaluate the results under the point of view of the used model that submits the animal to a second hypovolemia situation, the PM. Moreover, considering itself the proportion of the region splanchnic in the rat, can measure the seriousness of the two critical situation, hemorrhagic shock and PM, added in the activation of metabolic cascades and, therefore, in neutrophils activation. Therefore, according to the results in this study and literature the physiologic saline solution showed minor neutrophils sequestration in kidney, promoted smaller injury. However, is necessary that are accomplished other studies for comprehension of the current repercussions of the intensity and stay different degrees of ischemia and reperfusion.

\section{Conclusions}

Both critical situations in this model, controlled hemorrhagic shock followed by Pringle's maneuver, promoted neutrophils sequestration in the interstitium renal of rat, and the physiologic saline solution demonstrated minor mean, differentiating statistically of the others solutions.

\section{References}

1. Botha AJ, Moore FA, Moore EE, Sauaia A, Banerjee A, Peterson VM. Early neutrophil sequestrion after injury: a pathogenic mechanism for multiple organ failure. $\mathrm{J}$ Trauma. 1995;39:411-7.

2. Eurenius K, Brouse RO. Granulocyte kinetics after thermal injury. Am J Clin Pathol. 1973;60:337-42.

3. Martins Filho, O. Efeitos da isquemia e reperfusão hepática total no seqüestro de neutrófilos no pulmão, rim e íleo terminal e na produção de citocinas. Estudo experimental em ratos. (Tese - Doutorado). Faculdade de Medicina da Universidade de São Paulo.

4. Mantovani M, Fontelles MJ, Hirano ES, Morandin RC, Caputo LRG, Schenka AA. Isquemia e reperfusão hepática total associada ao estado de choque hemorrágico controlado: efeitos no seqüestro de neutrófilos no pulmão do rato. Acta Cir Bras. 2002;17:46-54.

5. Vedder NB, Fouty BW, Winn RK, Harlan JM, Rice CL. Role of neutrophils in generalized reperfusion injury associated with resuscitation from shock. Surgery. 1989;106: 509-16.

6. Moore FA, Moore EE, Haenel JB. Post-injury organ failure. In: Feliciano DV, Moore EE, Mattox KL (eds). Trauma. 3ed. Connecticut: Appleton; 1996. p.1205-19.

7. Özgüç H, Tokyay R, Kahveci N, Serdar Z, Gür ES. Hypertonic saline dextran alleviates hepatic injury in hypovolemic rats undergoing porta hepatic occlusion. Shock. 2003;19(4):383-4.

8. Flecknell PA. Laboratory animal anesthesia. 2ed. Londres: Academic Press; 1996.

9. Hirano ES, Mantovani M, Morandin RC. Modelo experimental de choque hemorrágico. Acta Cir Bras. 2003;18:465-9.

10. Fish RE. Pharmacology of injectable anesthetics. In: Kohn DF, Wixson SK, White WJ, Benson GJ. Anesthesia and analgesia in laboratory animals. Londres: Academic Press; 1982. p1-28.

11. Bellamy RF, Pederson DC, DeGuzman LR. Organ blood flow and the cause of death following massive hemorrhage. Circ Shock. 1984;14:113-27.

12. Drucker WR, Chadwick CDJ, Gann DS. Transcapillary refill in hemorrhage and shock. Arch Surg. 1981;116:1344-53.

13. Haljamae H. Interstitial fluid response. Clin Surg Internat. 1984;9:44-60.

14. Porter JM, Ivatury RR. In search of the optimal end points of resuscitation in trauma patients: a review. J Trauma. 
1998;44:908-14.

15. Gonce ME, Brackett DJ, Squires RA, Gibson DD, Balla AK, Lerner MR, McCay PB, Pennington LR.Development of circulatory and metabolic shock following transient portal triad occlusion. J Sur Res. 1995;59:534-543.

16. Lewinsohn R, Glover V, Sandler M. Development of benzylamine oxidase and monoamine oxidase $\mathrm{A}$ and $\mathrm{B}$ in man. Biochem Pharmacol. 1980;29:1221-30.

17. .Weihe WH. The laboratory rat. In: Poole TB, Robinson R. The UFAW handbook on the care and management of laboratory animals. 6ed. Inglaterra: Longman Scientific \& Technical; 1987. p.309-30.

18. Wang P, Hauptman JG, Chaudry IH. Hemorrhage produces depression in microvascular blod flow which persists despite fluid resuscitation. Circ Shock. 1990;32:307-18

19. Scannell G, Clark L, Waxman K: Regional flow during experimental hemorrhage and crystalloid resuscitation persistence of low flow to the splacnic organs. Resuscitation. 1992;23:217-25.

20. Mantovani M, Fontelles MJ, Hirano ES, Morandin RC, Caputo LRG, Schenka AA. Isquemia e reperfusão hepática total associada ao estado de choque hemorrágico controlado: efeitos no seqüestro de neutrófilos no fígado do rato. Rev Col Bras Cir. 2003;30:275-81.

21. Hirano ES, Mantovani M, Morandin RC. Isquemia e reperfusão hepática total em condições de normalidade e sob estado de choque hemorrágico controlado: efeitos no sequestro de neutrófilos no rim do rato. Acta Cir Bras. 2005;20:292-9.

22. Matheson PJ, Wilson MA, Garrison RN. Regulation of intestinal blood flow. J Surg Res. 2000;93:182-96.

23. Carden D, Xiao F, Moak C, Willis BH, Robinson-Jackson S, Alexander S. Neutrophil elastase promotes lung microvascular injury and proteolysis of endothelial cadherins. Am J Physiol. 1998;275:H385-92.

24. Deitch EA, XU D, Franko L, Ayala A, Chaudry IH. Evidence favoring the role of the gut as a cytokinegenerating organ in rats subjected to hemorrhagic shock. Shock. 1994;1:141-6.

25. Rizoli SB, Kapus A, Fan J, Li Yh, Marshall JC, Rotstein OD. Immunomodulatory effects of hypertonic resuscitation on the development of lung inflammation following hemorrhagic shock. J Immunol. 1998;161:6288-96.

26. Rhee P, Wang D, Ruff P, Austin B, DeBraux S, Wolcott K. Burris D, Ling G, Sun L. Human neutrophil activation and increased adhesion by various resuscitation fluids. Crit Care Med. 2000;28:74-8.

27. Delman K, Malek SK, Bundz S, Abumrad NN, Lang CH, Molina PE. Resuscitation with lactate Ringer's solution after hemorrhage: lack of cardiac toxicity. Shock. 1996;5:298-303.

28. Deb S, Martin B, Sun L, RuffP, Burris D, Rich N, DeBreux $\mathrm{S}$, Austin B, Rhee P. Resuscitation with lactate Ringer's solution in rats with hemorrhagic shock induces immediate apoptosis. J Trauma. 1999;46:582-9.

29. de Felippe Jr J, Timoner J, Velasco IT, Lopes OU, Rocha-eSilva M Jr. Treatment of refractory hypovolemic shock by 7,5\% sodium chloride injections. Lancet. 1980;2:1002-4.

30. Rocha e Silva M. Soluções hipertônicas. In: Rocha e Silva M. Choque. São Paulo: Atheneu; 1996. p.63-84.

31. Deitch EA, Shi HP, Feketeova E, Hauser CJ, Xu DZ. Hypertonic saline resuscitation limits neutrophil activation after trauma-hemorrhagic shock. Shock. 2003;4:328-33.

32. Gurfinkel V, Poggetti RS, Fontes B, da Costa Ferreira Novo F, Birolini. Hypertonic saline improves tissue oxygenation and reduces systemic and pulmonary inflammatory response caused by hemorrhagic shock. J Trauma. 2003;54:1137-45.

33. Angle N, Hoyt DB, Cabello-Passini R, Herdon-Remelius C, Loomis W, Junger WG. Hypertonic saline resuscitation reduces neutrophil margination by suppressing neutrophil L selectin expression. J Trauma. 1998;45:7-12.

34. Malcolm DS, Friedland M, Moore T, Beaauregard J, Hufnagel H, Wiesmann WP. Hypertonic saline resuscitation detrimentally affects renal function and survival in dehydrated rats. Circ Shock. 1993;40:69.

35. McKirman MD, William RL, Limjoco U, Ragland J, Gray CG. Hypertonic saline/dextran versus lactate Ringer's treatment for hemorrhage in dehydrated swine. Circ Shock. 1994;44: 238-46.

36. Wade CE, Kramer GC, Grady JJ, Fabian TC, Younes RN. Efficacy of hypertonic $7.5 \%$ saline and $6 \%$ dextran-70 in treating trauma: a meta-analysis of controlled clinical studies. Surgery. 1997;122:609-16.

\section{Correspondence:}

Elcio Shiyoiti Hirano

Av. Governador Pedro de Toledo, 638/91-3

13070-752 Campinas - SP - Brazil

elciohirano@ig.com.br
Conflict of interest: none

Financial source: none

Received: September 03, 2005

Review: October 16, 2005

Accepted: November 07, 2005

\section{How to cite this article:}

Hirano ES, Mantovani M, Morandin RC, Brito J, Pavani L. Total hepatic ischemia and reperfusion after state controlled hemorrhagic shock, with used of different solutions: effects of neutrophils sequestration in kidney of rats. Acta Cir Bras. [serial on the Internet] 2006 Jan-Feb;21(1). Available from URL: $\underline{\text { http://www.scielo.br/acb }}$ 